\title{
Effect of spray drying temperature differences on the gross nutritional composition and solubility and sinkability of goat milk powder
}

${ }$ Nurul'azah Mohd. Yaakub $^{1}$, Hana Mohd. Zaini ${ }^{1}$ and Lee Jian Xiang ${ }^{1}$

Faculty of Sustainable Agriculture, Universiti Malaysia Sabah, Locked Bag No. 3, 90509 Sandakan, Sabah, Malaysia

\begin{tabular}{|c|c|}
\hline ARTICLE INFO & \\
\hline $\begin{array}{l}\text { Accepted : } 22 \text { May } 2019 \\
\text { ublished: } 30 \text { June } 2019\end{array}$ & \multirow{3}{*}{$\begin{array}{l}\text { Spray drying is a method of drying powder via microencapsulated from liquid rapidly with hot } \\
\text { temperature in order to increase the shelf life. Hence, the objectives of the study are to investigate the } \\
\text { effect of spray drying temperature on the nutritional composition and physical properties of dry milk } \\
\text { powder of Saanen goat milk reared in Sandakan using maltodextrin as binder. The experiment tested the } \\
\text { inlet air temperature variation from } 140^{\circ} \mathrm{C}-220^{\circ} \mathrm{C} \text { with triplicates. The result was analyzed by a one-way } \\
\text { analysis variance (ANOVA) using the Statistical Analysis System (SAS) version } 9.4 \text {. The results showed } \\
\text { that there are significant }(p<0.05 \text { ) effects of inlet air temperature on dry milk powder in term of its protein } \\
\text { content, fat content, moisture content and the sinkability of the milk powder. Among all of the treatments, } \\
\text { the most sinkable temperature was at } 140^{\circ} \mathrm{C} \text {. Overall, the control powder, } \mathrm{T}_{0}=180^{\circ} \mathrm{C} \text {, however, is still } \\
\text { preferable as nutritional value (for both protein and fat) shown to be higher in this powder and have } \\
\text { acceptable moisture and physical properties. The finding of this study can be modified as for the further } \\
\text { investigation to improve the quality of milk powder in term of its nutritional value and physical properties. }\end{array}$} \\
\hline erature & \\
\hline & \\
\hline
\end{tabular}

Copyright:

(c) (i)

(O2019 by authors and BAURES. This work is licensed under the Creative Commons Attribution International License (CC By 4.0).

\section{Introduction}

As the demand for milk is rapidly increasing especially in developing countries, drying of milk can balance the supply of milk and can be stored for longer period forming a stable food reserve for future consumption (Caric and Kalab, 1987).The choice of goat milk over cow milk is due to its relatively brighter color, lower lactose and smaller fat globules (Tziboula-Clarke, 2003). Saanen dairy goat production under smallholder enterprising system has been promoted in developing countries to raise the income of rural people (FAO, 2010). Currently, Saanen goat producers in Sabah are directing towards value adding the fresh goat milk (Khandoker et al., 2018) through adaptation of technology.

The processing of goat milk was proven to prolong shelf life and decrease goaty odour, thus promotes consumer acceptability (Park, 2000). One of from several dairy product derivatives are in milk powder form from spray drying process. However, in milk powder production, the temperature applied during the spray drying process might affect the powder's nutritional content and reconstitution properties such as solubility, dispersability and sinkability (Freudig et al., 1999; Schuck, 2011; Seth et al, 2017).

Spray drying is a technology of transformation of liquid food or products into powder form and used more widely than any other drying method. The principle of spray drying involves moisture evaporation from an atomized feed by mixing the spraying process and drying medium which is typically air (Tonon et al., 2008). In order to obtain good microencapsulation efficiency, the main factors in spray drying that must be optimized are inlet air temperature, outlet air temperature and feed temperature (Liu et al., 2004, Seth et al, 2017).

Hence, it is crucial to optimize the spray drying combining system since it will influence the product quality and yield. Microencapsulation is the process of enclosing the active agent in particle or droplet using a coating or embedded in homogeneous or heterogeneous matrix at micro to nanoscale. Encapsulation coat and protect the core against stresses encountered during processing and prevent degradation during storage as well as reduce the stickiness during processing (Young et al., 2003).

Maltodextrins are hydrolysis products of starches and they are a mixture of saccharides with a broad molecular weight distribution between polysaccharides and oligosaccharides. Maltodextrins are known to improve particle size, bulk density, hygroscopicity and solubility (Chronakis, 1998; Danviriyakul et al., 2002).

In this study, maltodextrin is used as microencapsulation agent since it is widely applied in dry milk powder manufacture (Fonseca et al., 2011; Seth et al., 2017; Masum et al, 2019). We evaluated the opportunities to use maltodextrin as fillers in delivering nutritional and the physical quality of powders in production of goat

\section{Cite this article}

Yaakub, N.A.M., Zaini, H.M. and Xiang, L.J. 2019. Effect of spray drying temperature differences on the gross nutritional composition and solubility and sinkability of goat milk powder. Journal of Bangladesh Agricultural University, 17(2): 206-210. https://doi.org/10.3329/jbau.v17i2.41969 
milk powder with using different inlet temperature. The use of carriers or fillers may also improve the physical properties, especially the reconstitution properties of powder.

Therefore, effective process control is essential if dairy milk powder product is to be manufactured safely, compliance with regulatory requirement and acceptable product quality as well as low manufacturing costs.

\section{Materials and Methods}

\section{Raw Materials}

Goat milk samples were obtained from Saanen breed goat of Az-Zahra farm, Sandakan, Sabah. Five (5) L of milk samples were pooled from 32 goats at second lactation month. The milking session was done in the morning between $7 \mathrm{am}$ to 9am. Commercial maltodextrin (MOR-REX, Brazil) was obtained from local store in Kota Kinabalu, Sabah.

\section{Spray-drying and Experimental Design}

For each sample, $100 \mathrm{~g}$ of maltodextrin were dissolved in $1 \mathrm{~L}$ of goat milk to form viscous liquid as constant. The solution was prepared before spray-drying using a lab scale spray dryer (SD-1500, Xiang Yi, China) at the following inlet air temperature; $\left(\mathrm{T}_{\text {in }}\right): 140^{\circ} \mathrm{C}, 160^{\circ} \mathrm{C}$, $180^{\circ} \mathrm{C}, 200^{\circ} \mathrm{C}$ and $220^{\circ} \mathrm{C}$. Outlet air temperature, Tout cannot be directly controlled but depends on the inlet air temperature and the liquid feed rate. The Tout was kept in constant at $80^{\circ} \mathrm{C}$ (Young et al., 2003). The flow rate and pressure were kept in constant at $20 \mathrm{ml} / \mathrm{min}$ and 1.5 bars respectively (Zakarian and King, 1982). The finished milk powder was collected from the cyclone separator base for triplicates in the air-tight container and labeled.

In this experiment, $\mathrm{T}_{0}=180^{\circ} \mathrm{C}$ is being the inlet temperature control because it claimed to be the idealist and commonly used inlet temperature for industrial milk powder manufacturing with spray drying (Abd Almageed, 2009). Thus, the inlet temperature range was selected to experiment the best inlet temperature for goat milk nutritional dan physical quality. Four different inlet temperatures $\left(140^{\circ} \mathrm{C}, 160^{\circ} \mathrm{C}, 200^{\circ} \mathrm{C}\right.$ and $\left.220^{\circ} \mathrm{C}\right)$ with a control $\left(180^{\circ} \mathrm{C}\right)$ were produced in Table 1.

\section{Nutritional Analysis}

Moisture Content: The determination of moisture of dried milk sample is based on the protocol by AOAC (2006). The dish and its lid were prepared by preheating it in a hot air oven at $100 \pm 2{ }^{\circ} \mathrm{C}$ for an hour. Approximately 1 gram of dried milk sample was put in the dish, covered and immediately weighed. Then the uncovered dish and its lid was placed in the hot air oven and maintained at $102 \pm 2^{\circ} \mathrm{C}$ for 2 hours. The covered dish was then transferred to the desiccatorto cool at room temperature and immediately weighed. The process of drying, cooling and weighing were repeated until the successive weighing was constant.
Ash determination: The determination of ash of dried milk sample is based on the protocol by AOAC [8]. Approximately $3 \mathrm{~g}$ of the dried milk sample is weighed and put in a crucible. First, it was gently burned on a hot plate and then strongly placed in a muffle furnace at 550 $\pm 20^{\circ} \mathrm{C}$ for 5 hours until gray ash was obtained. The ash with crucible was transferred to the desiccator to cool and weighed.

Protein determination: Protein content was determined by using the Carbon-hydrogen-nitrogen (CHN) analyzer LECO $628 \mathrm{CHN}$ with Dumas method of nitrogen analysis (ISO-IDF, 2002). The sample was prepared by drying the milk powder inside the drying oven to eliminate any excess water. Approximately 0.15 gram of sample was weighed in the aluminum plate by using analytic balance and then wrapped. To allow the combustion of the sample, the samples were then placed in the autoloader.

From the furnace, combustion gasses were swept by the helium carrier gas (carbon and hydrogen evaluated at this point) and passing by the thermoelectrical cooler and finally collected into the aliquot collection system. Nitrogen determination occurred when the aliquot gas reached thermal conductivity cell. The amount of nitrogen, carbon and hydrogen were shown in the computer and the reading of nitrogen was taken. Crude protein content was then calculated based on the formula on Protein $(\%)=$ Nitrogen $x \quad 6.38$; where 6.38 is a protein factor for dairy product.

Fat determination: Fat content was determined according to Rose-Gottlieb method based on the protocol by AOAC (2006). The sample was prepared by adding 1 gram of the dried milk sample in extraction flask and poured with $9 \mathrm{ml}$ of warm distilled water. Consecutively, $1.25 \mathrm{ml}$ ammonia solution is added and mixed. Further, $10 \mathrm{ml}$ of ethyl alcohol, $25 \mathrm{ml}$ of diethyl ether and $25 \mathrm{ml}$ petroleum ether was added to the mixture and shook vigorously until the upper ethereal layer was completely separated and clear. Ethereal extract was collected and evaporated. The flask is then dried in the air oven at $102 \pm 2^{\circ} \mathrm{C}$ for two hours. It was then cooled in a desiccator and weighed. The process of cooling, weighing, and heating was repeated until constant weight and calculated in percent.

Carbohydrates determination: Carbohydrates content was determined by subtracting the percentage of ash, fat, and protein from the percentage of the total solids/dry matter (Merill and Watt, 1973).

\section{Physical Analysis}

Solubility Determination: The determination of solubility of dried milk sample is based on the protocol by AOAC (2006).

Five gram of dried milk sample was weighed, added $35 \mathrm{ml}$ of water into a $50 \mathrm{ml}$ centrifuge tube and placed in 
a water-bath maintained at $50 \pm 1^{\circ} \mathrm{C}$ for 5 minutes and shaken again. Next, the removal of fat of sample was done by sample mixture centrifuged for 10 mins at $2,000 \mathrm{rpm}$. The supernatant was collected in a preweighed beaker and oven dried at $102 \pm 2{ }^{\circ} \mathrm{C}$. The solubility index (\%) was calculated as the percentage of dried supernatant with respect of $5 \mathrm{~g}$ dried milk powder.

Sinkability determination: The determination of sinkability of dried milk is according to National Dairy Research Institute (NIDR) (Sathish Kumar et al., 2012). Sinkability is usually expressed as milligrams of powder that sink per minute per square centimeter of surface area. The spectrophotometer was first calibrated at $760 \mathrm{~nm}$ wavelength. The cuvette was half filled with distilled water and inserted in a spectrophotometer and the transmittance set as blank. 0.1 gram of a sample was taken and transferred to the cuvette that already contains $3.5 \mathrm{ml}$ of distilled water and the cuvette tapped 6 times before inserting it in the spectrophotometer. The transmittance measured $3-4$ times with intermittent tapping 6 times at $0,2 \& 4$ minutes interval.

Statistical analysis: A one-way analysis variance (ANOVA) was used to test the effect of spray drying temperature on the mean value of contents of proximate and physical characteristic of dried milk powder. The Statistical Analysis System (SAS) version 9.4 and Microsoft Excel 2010 are used for this analysis. The significant differences among means of different parameters were considered at $p<0.05$.

\section{Results and Discussion}

Nutritional compositions

Table 1. Nutritional compositions of goat milk spray-dried powder

\begin{tabular}{|c|c|c|c|c|c|c|}
\hline Treatment & $\begin{array}{c}\text { Temperature } \\
\left({ }^{\circ} \mathbf{C}\right)\end{array}$ & $\begin{array}{c}\text { Moisture } \\
(\%)\end{array}$ & $\begin{array}{l}\text { Ash } \\
(\%)\end{array}$ & $\begin{array}{c}\text { Protein } \\
(\%)\end{array}$ & $\begin{array}{l}\text { Fat } \\
(\%)\end{array}$ & $\begin{array}{c}\text { Carbohydrates } \\
(\%)\end{array}$ \\
\hline Fresh & - & $\begin{array}{c}88.75 \\
( \pm 0.04)\end{array}$ & $\begin{array}{c}0.78 \\
( \pm 0.01)\end{array}$ & $\begin{array}{c}2.30 \\
( \pm 0.02)\end{array}$ & $\begin{array}{c}3.47 \\
( \pm 0.09)\end{array}$ & $\begin{array}{c}4.71 \\
( \pm 0.10)\end{array}$ \\
\hline $\mathrm{T}_{1}$ & 140 & $\begin{array}{c}5.43^{\mathrm{a}} \\
( \pm 0.02)\end{array}$ & $\begin{array}{c}6.12^{\mathrm{a}} \\
( \pm 1.40)\end{array}$ & $\begin{array}{l}27.94^{a b} \\
( \pm 0.22)\end{array}$ & $\begin{array}{l}16.52^{\mathrm{c}} \\
( \pm 0.81)\end{array}$ & $\begin{array}{l}43.99^{\mathrm{b}} \\
( \pm 2.80)\end{array}$ \\
\hline $\mathrm{T}_{2}$ & 160 & $\begin{array}{c}5.04^{\mathrm{a}} \\
( \pm 0.07)\end{array}$ & $\begin{array}{c}4.45^{\mathrm{b}} \\
( \pm 0.91)\end{array}$ & $\begin{array}{l}27.38^{c} \\
( \pm 0.08)\end{array}$ & $\begin{array}{l}15.40^{c} \\
( \pm 1.10)\end{array}$ & $\begin{array}{l}46.05^{\mathrm{a}} \\
( \pm 1.88)\end{array}$ \\
\hline $\mathrm{T}_{0}$ (Control) & 180 & $\begin{array}{c}4.92^{\mathrm{a}} \\
( \pm 0.04)\end{array}$ & $\begin{array}{c}4.22^{\mathrm{b}} \\
( \pm 0.38)\end{array}$ & $\begin{array}{l}28.42^{a} \\
( \pm 0.11)\end{array}$ & $\begin{array}{l}19.07^{b} \\
( \pm 0.34)\end{array}$ & $\begin{array}{l}43.37^{b} \\
( \pm 2.11)\end{array}$ \\
\hline $\mathrm{T}_{3}$ & 200 & $\begin{array}{c}4.58^{\mathrm{a}} \\
( \pm 0.15)\end{array}$ & $\begin{array}{c}4.16^{\mathrm{b}} \\
( \pm 0.21)\end{array}$ & $\begin{array}{l}27.81^{b c} \\
( \pm 0.08)\end{array}$ & $\begin{array}{l}20.17^{a} \\
( \pm 0.31)\end{array}$ & $\begin{array}{l}43.28^{b} \\
( \pm 0.77)\end{array}$ \\
\hline $\mathrm{T}_{4}$ & 220 & $\begin{array}{c}4.40^{\mathrm{a}} \\
( \pm 0.11)\end{array}$ & $\begin{array}{c}4.04^{\mathrm{b}} \\
( \pm 0.20)\end{array}$ & $\begin{array}{l}28.39^{a} \\
( \pm 0.21)\end{array}$ & $\begin{array}{l}16.52^{\mathrm{bc}} \\
( \pm 0.69)\end{array}$ & $\begin{array}{l}46.65^{a} \\
( \pm 1.40)\end{array}$ \\
\hline
\end{tabular}

Data are means of triplicates \pm SEM. Different letters in the same column indicate significant difference at $p<0.05$.

Protein content of spray dried powder reported from Table 1 were ranges from $27.38-28.39 \%$ and slightly had higher average as reported from Park (2000) and Fonseca et al. (2011) with Masum et al. (2019) respectively $27 \%, 25.6 \%$ and $14.07-14.27 \%$ protein. The inclusion of more filler other than maltodextrin from milk powder production might cause the decrease of protein content.
The moisture content of milk is one of the major factors that affect stability of the stored food (Udensi and Okaka, 2000). The trend of moisture content was inversely proportional to the temperature of drying and found to be highest in fresh goat milk (Table 1). The results of moisture content shown that all drying temperature resulted to less than $5 \%$ moisture content. Previous research also found that an increase in inlet air temperature of spray drying produce low moisture powder (Abd Almageed, 2009 \& Mestry et al., 2011). The moisture content in spray dried powder was higher as compared to goat milk powder with soy lecithin (Fonseca et al., 2011), and goat milk powder ratioed with lactose (Masum et al, 2019). Higher inlet air temperature usually desirable through energy efficiency perspective as it may improve the bulk density and avoid hardening case on the surface of powder particles (Pisecky, 1997).

From Table 1, ash content was determined in order to measure the total amount of minerals present in a milk powder. All ash content of spray dried goat milk powder ranges from 4.04-6.12 \% shown from Table 1. In another spray dried milk study (Masum et al., 2019), the reported ash content reported ofmilk powder (2.69$2.74 \%$ ) was lower and the ash content did not significantly affected by lactose-maltodextrin ratio. However, this study shown that the lowest inlet temperature gave higher ash content and the results were in comparable with Park (2000). The ash content of all treatment is higher compared to fresh goat milk, as agreed in previous study (Filiz, 2013). Unlike vitamins, mineral is less sensitive to physical and chemical factors (Satpute and Annapure, 2013).
Based on Table 1, fat content was highest as inlet temperature condition is at $200^{\circ} \mathrm{C}$. Maltodextrins and constituents of whey from the goat milk such as globular proteins and lactose might increase the stability of fat emulsions during processing, which decreases the free fat content and improves the reconstitution properties of powders during rehydrating (Erbay and Koca, 2015).The lower fat content from other inlet temperature was also might be resulted due to incomplete evaporation which 
causes the cracks in the membrane inducing subsequent premature release and degradation of ingredient including fat content (Zakarian and King, 1982). On the other hand, the possible reason why the fat content was low on $140^{\circ} \mathrm{C}$ and $160^{\circ} \mathrm{C}$ due to the lower temperature that was used for drying. Thus, led on slower moisture removal. As a result, it slowed down the hardening of the powder particle surface which resulted to fat leakage from encapsulation (Nijdam and Langrish, 2006) .However, spray-drying did improved fat content as compared to fat content in fresh goat milk (Table 1).

The carbohydrate content was related with the increase content of ash, moisture, fat and protein content. Thus, it can be seen that $\mathrm{T}_{2}\left(160^{\circ} \mathrm{C}\right)$ and $\mathrm{T}_{4}\left(220^{\circ} \mathrm{C}\right)$ was significantly higher as compared to other treatments. Nevertheless, this study had shown that the carbohydrate content was higher as compared with $25.48 \%$ carbohydrate content of Osmanabadi goat (Reddy et al., 2014). Spray-dried goat milk powder was also seen to improve carbohydrate content as compared to fresh goat milk powder.

\section{Physical properties}

From the data obtained in Table 2, the effect of temperature on the solubility of milk powder was not significant $(p>0.05)$ to one another. It has been found (Sweetsur, 1976) that the insoluble material from dried milk powder is casein and some denatured whey protein. This could be due to adverse effects of high inlet air temperature on the protein and carbohydrate present in milk sample (Fox, 1992). Results of goat milk powder's sinkability from Table 2 was comparable as reported from Masum et al. (2019), except for inlet temperature of $\mathrm{T}_{2}\left(160^{\circ} \mathrm{C}\right)$. Poorer solubility for $\mathrm{T}_{2}$ shown thes olubility might be due protein denaturation. Several factors such as system of atomization, dryer type, preheat treatment of the milk, total solids and storage time have been reported to affect solubility (Bloor and Boag, 1981). However, the solubility of all treatments are higher than those sinkability percent of goat mik powder added with soy lecithin as reported by Seth et al. (2017). Addition of sucrose in granulated form, not very fine powder as an additive in milk powder however, improved the milk solubility (Galet et al., 2004).

Based on Table 2, $\mathrm{T}_{1}\left(140^{\circ} \mathrm{C}\right)$ have the highest sinkability mean compared the other. It is the ability of powder particles to overcome the surface tension of water and sink into the water. The higher the mean sinkability, the faster the powder particles to sink as compared to control $\left(\mathrm{T}_{0}\right)=140^{\circ} \mathrm{C}$. This might be due to the treatment have higher bulk density compared the other powder as agreed by previous researcher (Zakarian and King, 1982). Another factor that can affect the sinkabilty is the density of solids, amount of air entrapped in the powder particle and the amount of air between particles. Despite of lowest fat content among all treatment, $\mathrm{T}_{1}\left(140^{\circ} \mathrm{C}\right)$ shows better sinkability and less likely to float as compared to the rest due to lesser surface hydrophobic characteristics as observed in cocoa powder (Galet et al., 2004).

Table 2. Physical properties of goat milk spray-dried powder

\begin{tabular}{|c|c|c|c|c|c|}
\hline \multirow{2}{*}{ Treatment } & \multirow{2}{*}{$\begin{array}{c}\text { Temperature } \\
\left({ }^{\circ} \mathrm{C}\right)\end{array}$} & \multirow{2}{*}{$\begin{array}{c}\text { Solubility } \\
(\%)\end{array}$} & \multicolumn{3}{|c|}{ Sinkability (mean) } \\
\hline & & & Omin & $2 \mathrm{~min}$ & $4 \mathrm{~min}$ \\
\hline \multirow[t]{2}{*}{$\mathrm{T}_{1}$} & 140 & $92.31^{\mathrm{a}}$ & $0.22^{\mathrm{a}}$ & $0.38^{\mathrm{a}}$ & $0.46^{\mathrm{a}}$ \\
\hline & & $( \pm 1.43)$ & $( \pm 0.04)$ & $( \pm 0.02)$ & $( \pm 0.01)$ \\
\hline \multirow[t]{2}{*}{$\mathrm{T}_{2}$} & 160 & $85.24^{\mathrm{a}}$ & $0.16^{\mathrm{b}}$ & $0.26^{\mathrm{b}}$ & $0.32^{\mathrm{b}}$ \\
\hline & & $( \pm 7.25)$ & $( \pm 0.02)$ & $( \pm 0.02)$ & $( \pm 0.01)$ \\
\hline \multirow[t]{2}{*}{$\mathrm{T}_{0}($ Control $)$} & 180 & $94.09^{\mathrm{a}}$ & $0.11^{\mathrm{bc}}$ & $0.15^{\mathrm{c}}$ & $0.20^{\mathrm{cd}}$ \\
\hline & & $( \pm 3.88)$ & $( \pm 0.00)$ & $( \pm 0.00)$ & $( \pm 0.01)$ \\
\hline \multirow[t]{2}{*}{$\mathrm{T}_{3}$} & 200 & $93.41^{\mathrm{a}}$ & $0.12^{\mathrm{bc}}$ & $0.16^{\mathrm{c}}$ & $0.22^{\mathrm{c}}$ \\
\hline & & $( \pm 2.72)$ & $( \pm 0.00)$ & $( \pm 0.00)$ & $( \pm 0.00)$ \\
\hline \multirow[t]{2}{*}{$\mathrm{T}_{4}$} & 220 & $92.88^{\mathrm{a}}$ & $0.09^{c}$ & $0.14^{\mathrm{c}}$ & $0.19^{\mathrm{d}}$ \\
\hline & & $( \pm 3.80)$ & $( \pm 0.00)$ & $( \pm 0.01)$ & $( \pm 0.01)$ \\
\hline
\end{tabular}

Data are means of triplicates \pm SEM. Different letters in the same column indicate significant difference at $p<0.05$.

\section{Conclusion}

As a conclusion, spray dried goat milk has changed the nutritional composition of fresh goat milk. Temperature inlet for control $\left(180^{\circ} \mathrm{C}\right)$ proven to have the best temperature for protein content but increasing temperature to $\left(\mathrm{T}_{3}\right) 200^{\circ} \mathrm{C}$ retained fat content compared to other treatments. In terms of physical properties, all treatments did not give any difference in solubility. Lowest inlet temperature was observed to have highest mean sinkability of spray dried goat milk with maltodextrin as filler.

\section{Acknowledgement}

The authors wish to thank Faculty of Sustainable Agriculture for partially funding this project, Ms. Raiha Ab. Rahman for allowing the researcher to obtain fresh sample from Az-Zahra farm and Ms. Susyana Samiran for her assistance on using laboratory scale spray dryer (SD-1500, Xiang Yi, China).

\section{References}

Abd Almageed, E. T. E. 2009. Properties of milk powder made from cow, goat and camel. Bachelor of Science dissertation. University of Khartoum.

AOAC. 2006. Official Method of Analysis.18th edition. Association of Official Analytical Chemists. AOAC Press, Gaithersburg. 
Bloore, C. G. and Boag, I. F. 1981. Some factor affecting the viscosity of concentrated skim milk powder. New Zealand Journal of Dairy Science and Technology, 16: 143-154.

Caric, M. and Kalab, 1987. Effect of drying technique on milk powder quality and microstructure: a review. Food Microstructure, 6: $171-180$.

Chronakis, I. S. 1998. On the molecular characteristics, compositional properties, and structural-functional mechanisms of maltodextrins: A review. Crit. Rev. Food Sci. Nutr, 38: 599-637. https://doi.org/10.1080/10408699891274327

Danviriyakul, S., D. J. McClements, E. Decker, W. W. Nawar, and P. Chinachotti. 2002. Physical stability of spray-dried milk fat emulsion as affected by emulsifiers and processing conditions. Journal of Food Science, 67: 2183-2189. https://doi.org/10.1111/j.1365-2621.2002.tb09524.x

Fonseca, C. R., Bento, M. S. G., Quintero, E. S. M., Gabas, A. L. and Oliveira, A. F. 2011. Physical properties of goat milk powder with soy lecithin added before spray drying. International Journal of Food Science and Technology, 46 : 608-611. https://doi.org/10.1111/j.1365-2621.2010.02527.x

Fox, P.E. 1992. Advanced Dairy Chemistry Vol. 1. pp. 753-757, Elsevier Science Publishers Ltd. London and New York.

Freudig, B., Hogekamp, S. and Schubert, H. 1999. Dispersion of powders in liquids in a stirred vessel. Chemical Engineering Process, 38: 525-532. https://doi.org/10.1016/S0255-2701(99)00049-5

Galet, L., Vu, T.O., Oulahna, D. and Fages, J. 2004. The wetting behavior and dispersion rate of cocoa powder in water. Food and Bioproducts Processing, 82(2): 298-303. https://doi.org/10.1205/fbio.82.4.298.56399.

Khandoker, M. A. M. Y, Afini, A. and Azwan, A. 2018. Productive and reproductive performance of Saanen goat at AZ-Zahra farm of Sandakan in Malaysia. Bangladesh Journal of Animal Science, 47(1):1-12. https://doi.org/10.3329/bjas.v47i1.39395

Liu, Z., Zhou, J., Zeng, Y., and Ouyang, X. 2004. The enhancement and encapsulation of Agaricusbisporus flavor. Journal of Food Engineering, 65: 391-396. https://doi.org/10.1016/j.jfoodeng.2004.01.038

Ma, U.V., Ziegler, G. R. and Floros, J. D. 2008. Effect of sucrose on physical properties of spray-dried whole milk powder. Journal of Food Science, 73(9): 431-438 https://doi.org/10.1111/i.1750-3841.2008.00955.x

Ma, U.V., Ziegler, G. R. and Floros, J. D. 2008. Effect of sucrose on physical properties of spray-dried whole milk powder. Journal of Food Science, 73(9): 431-438. DOI:10.1111/j.1750-3841.2008.00955.x https://doi.org/10.1111/j.1750-3841.2008.00955.x

Masum, A. K. M., Chandrapala, J., Adhikari, B., Huppertz, T. and Zisu, B. 2019. Effect of lactose-to-maltodextrin ratio on emulsion stability and physicochemical properties of spraydried infant milk formula powders. Journal of Food Engineering, 254: 34-41. https://doi.org/10.1016/j.jfoodeng.2019.02.023

Merrill, A. L. and Watt, B. K. 1973. Carbohydrate. In: Energy Value of Foods - Basis and Derivation. pp, 2-3. USDA, USA.

Mestry, A.P., Mujumdar, A. S. and Thorat, B. N. 2011. Optimization of spray drying of an innovative functional food: fermented mixed juice of carrot and watermelon. Drying Technology, 29(10): 1121-1131. https://doi.org/10.1080/07373937.2011.566968

Nijdam, J. J. and Langrish, T. A. G. 2006. The effect of surface composition on the functional properties of milk powders. Journal of Food Engineering, 77: 919-925. https://doi.org/10.1016/j.jfoodeng.2005.08.020

Oldfield, D. J., Singh, H. and Taylor, M. W. 2005. Effect of preheating and other process parameters on whey protein reactions during skim milk powder manufacture. International Dairy Journal. 15(5): 501-511. https://doi.org/10.1016/j.idairyj.2004.09.004

Park, Y. W. 2000. Comparison of mineral and cholesterol composition of different commercial goat milk products manufactured in USA. Small Ruminant Research, 37 (1-2): 115-124. https://doi.org/10.1016/S0921-4488(99)00144-3

Pisecky, J. 1997. Handbook of Milk Powder Manufacture. Niro, Copenhagen.

Reddy,R. S.,Ramacandra, C. T., Hiregoudar, S., Nidoni, U., Ram, J. and Kammar, M. 2014. Influence of processing conditions on functional and reconstitution properties of milk powder made from Osmanabadi goat milk by spray drying. Small Ruminant Research, 119:130-137. https://doi.org/10.1016/j.smallrumres.2014.01.013

Sathish Kumar, M. H., Sharma, P., Khamrui, K. and Singh, R. R. B. 2012. A Laboratory Manual on Condensed and Dried Milks. $1^{\text {st }}$ edition, pp, 62. Intech Printers \& Publishers. Haryana, India.

Satpute, M. and Annapure, U. 2013. Approaches for delivery of heat sensitive nutrients through food systems for selection of appropriate processing techniques: A Review. Journal of Hygienic Engineering and Design, 4: 71-92.

Schuck, P. 2011. Milk powder: Physical and functional properties of milk powders in Encyclopedia of Dairy Sciences, pp. 117124, 2nd ed. Vol. 2. J. W. Fuquay, P. F. Fox and P. L. H. McSweeney, ed. Elsevier/Academic Press, London, UK. https://doi.org/10.1016/B978-0-12-374407-4.00122-9

Seth, D., Mishra, H. N. and Deka, S. C. 2017. Functional and reconstitution properties of spray-dried sweetened yogurt powder as influenced by processing conditions. International Journal of Food Properties, 20(7): 16031611. https://doi.org/10.1080/10942912.2016.1214965

Sharma, A., Jana, A. H. and R. S. Chavan. 2012. Functionality of milk powders for end use applications-A Review. Comprehensive Reviews in Food Science and Food Safety, 11(5): 518-528. https://doi.org/10.1111/j.1541-4337.2012.00199.x

Sweetsur, A. M. W. 1976. The stability of instantised skim milk powder to hot coffee. Journal of the Society of Dairy Technology, 29:157-160. https://doi.org/10.1111/j.1471-0307.1976.tb00424.x

Tonon, R. V., Brabet, C. and Hubinger, M. D. 2008. Influence of process conditions on the physicochemical properties of açai (Euterpe oleraceae Mart.) powder produced by spray drying. Journal of Food Engineering, 88(3): 411-441. https://doi.org/10.1016/j.jfoodeng.2008.02.029

Tonon, R. V., Brabet, C. and Hubinger, M. D. 2008. Influence of process conditions on the physicochemical properties of açai (Euterpe oleraceae Mart.) powder produced by spray drying. Journal of Food Engineering, 88(3): 411-441

Udensi, E. A. and Okaka, J. C. 2000. Predicting the Effect of blanching, drying temperature and particle size profile on the dispersibility of cowpea flour. Nigerian Food Journal, 18: 25-31. https://doi.org/10.4314/gjpas.v6i4.16170

Yangilar, F. 2013. As a Potentially Functional Food: Goats' Milk and Products. Journal of Food and Nutrition Research, 1(4): 68-81. DOI: 10.12691/jfnr-1-4-6

Young, S. L., Sarda, X. and Rosenberg, M. 1993. Microencapsulation properties of whey proteins: Microencapsulation of anhydrous milk fat. Journal of Dairy Science, 2868-2877. https://doi.org/10.3168/jds.S0022-0302(93)77625-0

Zakarian, A. J. and King, C. J. 1982. Volatiles loss in the zone during spray drying of emulsions. Industrial Engineering Chemistry Process Design and Development, 21: 107-113. https://doi.org/10.1021/i200016a019 